\title{
Cultivar, Plant Height and Fungicide for Integrated Control of Ramularia Spot and Increased Cotton Yield
}

\author{
Hugo Manoel de Souza \\ Federal University of Mato Grosso do Sul, Chapadão do Sul, MS, Brasil. \\ https://orcid.org/0000-0002-6135-2363 \\ Email: hugo_manoel12@hotmail.com
}

Alfredo Riciere Dias

Chapadão Agricultural Research Support Foundation, Chapadão do Sul, MS, Brasil.

https://orcid.org/0000-0003-1628-0441

Email: alfredo@fundacaochapadao.com.br

Gustavo de Faria Theodoro (Corresponding author)

Federal University of Mato Grosso do Sul, Faculty of Veterinary Medicine and Animal

Science, Campo Grande, Mato Grosso do Sul, Brazil.

https://orcid.org/0000-0002-1230-2124

Email: gustavo.theodoro@ufms.br

Christian Rones Wruck Souza Osório

Federal University of Mato Grosso do Sul, Chapadão do Sul, MS, Brasil.

https://orcid.org/0000-0002-0111-3424

Email: c.osorio@hotmail.com

Fernando Fagner Magalhães

Federal University of Mato Grosso do Sul, Chapadão do Sul, MS, Brasil.

https://orcid.org/0000-0001-5168-0446 
Email: magalhaes.fernandof@gmail.com

Received: Nov. 20, 2019

doi:10.5296/jas.v8i2.15871
Accepted: Dec. 23, 2019 Published: Jan. 3, 2020

URL: https://doi.org/10.5296/jas.v8i2.15871

\begin{abstract}
Cotton is a crop with a high economic value, usually sprayed with large amounts of pesticides to control pests and diseases. Ramularia spot is a foliar disease that cause early defoliation and can compromise cotton yield; however, there is a need of information about the interaction of cultivars and plant height as a tool to improve ramularia control and increase yield. The objective of this study was to evaluate the effects of the interaction between plant height, cultivar, and fungicides applied to the severity of the leaf spot and cotton yield. The experiment was carried on during the 2014/15 crop season in Chapadão do Sul, MS, Brazil. A randomized complete block design in a $2 \times 3 \times 3$ factorial scheme was used, where the factors were plant heights (1 and $1.5 \mathrm{~m}$ ), cultivar (FMT 701, FM 975, and FM 944) and type of fungicide (Negative control, FT1, and FT2). The fungicidal treatments consisted of sequential sprays of different fungicides, including the triazole, strobilurin, and carboxamide groups, recommended to farmers. The cultivar FM 975 showed greater ramularia spot progress curve when grown at $1 \mathrm{~m}$ height and without fungicide spray. The fungicides were efficient in reducing the severity of the ramularia spot and their use in shorter plants $(1 \mathrm{~m})$ increased yield. The cultivar FM 975 had the highest total yield.
\end{abstract}

Keywords: Ramularia areola, Gossypium hirsutum, sustainability, management

\title{
1. Introduction
}

Cotton (Gossypium hirsutum L.) is a crop of great importance to many countries worldwide; however the use of large amounts of pesticides can cause environmental imbalance and economic losses (Pimentel, 2005). Around the world, there is an emerging trend in the demand for generic products from sustainable companies, especially in the textile industry sector (Garcia et al., 2019), which has encouraged the search for methodologies for sustainable cotton crops (Zulfiqar and Thapa, 2018).

The challenge in reaching sustainable crops is the need to fertilize and protect plants against a large number of pests and diseases with the lowest possible use of pesticides (Prakash et al., 2019; Guazina et al., 2020). Ramularia areola is the agent causal of one of the main diseases that cause damage to cotton (Ascari et al., 2016), especially in cities located in Midwest Brazil, where cotton is a very important crop (Silva et al., 2010), because the climatic conditions are suitable for its development (Lima et al., 2010).

In high severity conditions, ramularia spot can cause premature defoliation, especially in the lower part where the onset of symptoms is observed and it may result in reduced yield and fiber quality (Johnson et al., 2013; Suassuna \& Coutinho, 2015). The control of ramularia 
spot has been accomplished mainly through the use of fungicides, for which from five to eight sprays are recommended (Girotto et al., 2013). Although practical, this control method should be carefully employed to avoid the occurrence of fungicide-resistant pathogen populations (Volponi et al., 2014). According to Silva et al. (2017), although chemical control is efficient to control leaf spot, the development of new strategies is essential to achieve efficient and sustainable integrated disease control. Thus, it is necessary to adopt management that integrates all control methods (Dias and Theodoro, 2017).

Cultural control is based on the use of procedures that can act on the relationship between pathogen, host, and the environment to make the establishment and development of the disease less favorable (Agrios, 2005). Manipulation of plant size is a technique that can assist in the control of leaf spot. According to Monteith and Unsworth (1990), plant height, architecture, and leaf area directly interfere with the microclimate inside the plant canopy. Another very important tool in the control of leaf spot is the use of cultivars with disease resistance (Shete et al., 2018). However, resistant commercial cultivars have shown different reactions to ramularia spot as a function of the environment, indicating the existence of genetic variability of the pathogen (Cia et al., 2013; Silva et al., 2017).

The integration of cotton disease control methods can improve leaf spot control and complement or reduce the number of chemical sprays (Dias and Theodoro, 2017). The objective of this work was to evaluate the interaction effects among plant height, cotton cultivar, and fungicide spray for the control of the leaf spot and their effects on cotton yield.

\section{Material and Methods}

The experiment was carried on under field conditions from December 2014 to August 2015, in Chapadão do Sul, MS, Brazil, located at $18^{\circ} 41^{\prime} 33^{\prime \prime} \mathrm{S}, 52^{\circ} 40^{\prime} 45^{\prime \prime} \mathrm{W}$, at an altitude of $810 \mathrm{~m}$ with a typical tropical climate, with prolonged dry periods during winter. The soil of the area was classified as Dystrophic Red Latosol and samples were collected from the superficial soil layer, at a depth from 0 to $0.20 \mathrm{~m}$. Its chemical characteristics were $\mathrm{pH}\left(\mathrm{CaCl}_{2}\right)$ 5.0, $\mathrm{Ca} 5.15$ $\mathrm{cmol}_{\mathrm{c}} \cdot \mathrm{dm}^{-3}, \mathrm{Mg} 0.80 \mathrm{cmol}_{\mathrm{c}} \cdot \mathrm{dm}^{-3}, \mathrm{Al} 0.04 \mathrm{cmol}_{\mathrm{c}} \cdot \mathrm{dm}^{-3}, \mathrm{~K}$ (Mehlich) $87 \mathrm{mg} \cdot \mathrm{dm}^{-3}, \mathrm{P}$ (Resin) $46.55 \mathrm{mg} . \mathrm{dm}^{-3}$, Organic Matter $43.20 \mathrm{~g} . \mathrm{dm}^{-3}$ and Base Saturation $57.10 \%$. Subsequently, the soil was fertilized according to the crop recommendations proposed by Sousa and Lobato (2004). Sowing was on December 22, 2014, in a conventional crop system in an area previously cultivated with corn. There was $0.90 \mathrm{~m}$ between rows and a population of 90,000 plants ha ${ }^{-1}$ for each cultivar.

The experimental design was a randomized complete block, arranged in a $2 \times 3 \times 3$ factorial scheme, where the factors were plant height $(1 \mathrm{~m}$ and $1.5 \mathrm{~m}$ ), cultivar (FMT 701, FM 975, and FM 944) and fungicidal treatments (Table 1), recommended to farmers, sprayed in specific phenological stages defined by Marur and Ruano (2001), with four repetitions. The plots consisted of four $12 \mathrm{~m}$ long plant lines, and the useful area was the two central lines excluding four meters from each end. The desired plant heights were obtained using mepiquat chloride with $150 \mathrm{~g}$ of the active ingredient (a.i.) for the cultivars FMT 701 and FM 975 and 100 g. of i.a. for the cultivar FM 944 (Cordão Sobrinho et al., 2007). 
Table 1. Fungicidal treatments and active ingredients used in cotton crop. Chapadão do Sul, MS, Brazil. Crop season 2014/5

\begin{tabular}{|c|c|c|c|}
\hline $\begin{array}{l}\text { Fungicides } \\
\text { treatments (FT) }\end{array}$ & $\begin{array}{c}\text { Active } \\
\text { ingredients }\end{array}$ & $\begin{array}{c}\text { Phenological stage } \\
\text { (+days) in spray }\end{array}$ & $\begin{array}{l}\text { Active ingredient } \\
\text { dose }\left(\mathrm{g} \cdot \mathrm{L}^{-1}\right)\end{array}$ \\
\hline Negative Control & - & - & - \\
\hline \multirow{6}{*}{ FT1 } & $\begin{array}{c}\text { Pyraclostrobin + } \\
\text { Fluxapyroxad }\end{array}$ & B1 & $333+167$ \\
\hline & $\begin{array}{l}\text { Trifloxystrobin } \\
+ \text { Protioconazol }\end{array}$ & $\mathrm{B} 1+15$ & $150+175$ \\
\hline & $\begin{array}{l}\text { Pyraclostrobin } \\
+ \text { Fluxapyroxad }\end{array}$ & $\mathrm{B} 1+30$ & $333+167$ \\
\hline & $\begin{array}{c}\text { Pyraclostrobin + } \\
\text { Fluxapyroxad }\end{array}$ & $\mathrm{B} 1+45$ & $333+167$ \\
\hline & $\begin{array}{c}\text { Pyraclostrobin + } \\
\text { Fluxapyroxad }\end{array}$ & $\mathrm{B} 1+60$ & $333+167$ \\
\hline & $\begin{array}{l}\text { Trifloxystrobin } \\
+ \text { Protioconazol }\end{array}$ & $\mathrm{B} 1+75$ & $150+175$ \\
\hline \multirow{6}{*}{ FT2 } & $\begin{array}{l}\text { Azoxystrobin }+ \\
\text { Difenoconazole }\end{array}$ & B1 & $200+125$ \\
\hline & Difenoconazole & $\mathrm{B} 1+15$ & 250 \\
\hline & $\begin{array}{l}\text { Azoxystrobin }+ \\
\text { Difenoconazole }\end{array}$ & $\mathrm{B} 1+30$ & $200+125$ \\
\hline & $\begin{array}{l}\text { Azoxystrobin }+ \\
\text { Difenoconazole }\end{array}$ & $\mathrm{B} 1+45$ & $200+125$ \\
\hline & $\begin{array}{l}\text { Azoxystrobin }+ \\
\text { Difenoconazole }\end{array}$ & $\mathrm{B} 1+60$ & $200+125$ \\
\hline & Difenoconazole & $\mathrm{B} 1+75$ & 250 \\
\hline
\end{tabular}

Fungicide and growth regulator sprays were applied with a constant pressure $\mathrm{CO}_{2}$ sprayer with a $3 \mathrm{~m}$ boom and six spray tips (XR 11002) spaced $0.50 \mathrm{~m}$ apart. A working pressure of $300 \mathrm{kPa}$ was used and the spray volume was $150 \mathrm{~L} \mathrm{ha}^{-1}$. Pest management in the experimental area was similarly done for the three cultivars, in accordance with the recommendations available from the Ministry of Agriculture, Livestock and Supply (Mapa, 2019). 
Disease severity assessments were performed using the diagrammatic scale proposed by Aquino et al. (2008). Five severity assessments were performed on 20 random leaves in both the lower portion and the upper portion of all plants located in the two central lines of each plot. After quantification of severity, the area under the disease progress curve (AUDPC) was estimated, according to Campbell and Madden (1990), in the lower portion (SVLOW), upper portion (SVUP) and whole cotton plants (SVWH). To determine yield, the harvest of bolls was manually and separately done for the upper (YUP) and lower (YLOW) portion of the plants on August 24, 2015.

Data were subjected to analysis of variance and the means compared by the Scott Knott test at $5 \%$ significance.

\section{Results and Discussion}

The symptoms of ramularia spot were detected at 89 days after plant emergence, as there were favorable climatic conditions for the occurrence of the disease during this study (climatic data obtained from Chapadão do Sul, MS, not shown). Temperatures were between 25 and $30{ }^{\circ} \mathrm{C}$ and relative air humidity was $80 \%$ (Rathaiah, 1977).

Plant height, cultivar, and fungicidal treatment interacted with the severity of leaf spot in the upper portion and whole plant (Table 2). However, this behavior was not observed in the lower portion, which exhibited significant differences for plant height, cultivar, and fungicide treatment factors alone.

Table 2. F values for area under ramularia spot progress curve in the lower portion (SVLOW), upper portion (SVUP) and whole cotton plants (SVWH). Chapadão do Sul, MS. Crop season $2014 / 5$

\begin{tabular}{lccc}
\hline Variation factors & \multicolumn{3}{c}{ F value } \\
\cline { 2 - 4 } & SVLOW & SVUP & SVWH \\
\hline Plant height (H) & $41,5429^{*}$ & $62,5748^{*}$ & $52,4355^{*}$ \\
Cultivar (C) & $24,9398^{*}$ & $78,6604^{*}$ & $35,7202^{*}$ \\
Fungicide treatment (FT) & $222,4805^{*}$ & $110,0359^{*}$ & $237,6669^{*}$ \\
H x C & $1,6629^{\mathrm{ns}}$ & $13,8221^{*}$ & $3,1639^{\mathrm{ns}}$ \\
H x FT & $2,3774^{\mathrm{ns}}$ & $6,8609^{*}$ & $3,5227^{*}$ \\
FT x C & $2,5027^{\mathrm{ns}}$ & $6,1109^{*}$ & $3,1857^{*}$ \\
H x C x FT & $2,5425^{\mathrm{ns}}$ & $4,0825^{*}$ & $2,9382^{*}$ \\
\hline VC $(\%)$ & 16,70 & 13,55 & 14,78 \\
\hline
\end{tabular}

* significant to $5 \%$ probability; ns: not significant

In Table 3 there are the results of disease progression in the lower portion of the plant. Plant height influenced the development of the lower leaf portion, such that cotton plants with a lower height $(1 \mathrm{~m})$ presented higher SVLOW values than did the taller plants. Marois et al. (2004) reported that cotton height was highly correlated with relative humidity and temperature inside the plant canopy and the change in plant size directly influenced these factors. Agrios (2005) determined that these factors are essential for the development of diseases and may favor or prevent their development.

The cultivar FMT 701 had a lower SVLOW value, followed by cultivars FM 944 and FM 975 
(Table 3). The difference between the behavior of cotton cultivars in relation to disease severity according to Punit et al. (1997) may be related to the histochemical, morphological, and anatomical characteristics of each cultivar; thus, these factors may result in higher or lower susceptibility of the cultivars to the disease.

The use of FT1 and FT2 reduced the SVLOW values in relation to that of the control, demonstrating that these fungicides were efficient in reducing the severity of leaf spot. FT1 and FT2 have as a constituent that was efficient in the first spray; it is a strobilurin group fungicide, which allowed for efficient control. According to Suassuna and Coutinho (2015), the use of strobilurin group fungicide as soon as the first symptoms appear allows for the efficient control of leaf spot.

Table 3. Area under ramularia spot progress curve in the lower portion (SVLOW) in two cotton plants height, three cultivars and three fungicides treatments. Chapadão do Sul, MS, Brazil. Crop season 2014/5

\begin{tabular}{lc}
\hline Plant height $(\mathrm{m})$ & SVLOW \\
\hline 1,0 & $291,05^{\mathrm{a}}$ \\
1,5 & $180,90^{\mathrm{b}}$ \\
\hline Cultivar & \\
\hline FMT 701 & $157,44^{\mathrm{c}}$ \\
FM 975 & $313,33^{\mathrm{a}}$ \\
FM 944 & $237,16^{\mathrm{b}}$ \\
\hline Fungicide treatment $*$ & \\
\hline Negative Control & $501,33^{\mathrm{a}}$ \\
FT1 & $93,78^{\mathrm{b}}$ \\
FT2 & $112,81^{\mathrm{b}}$ \\
\hline VC \% & 16,70 \\
\hline
\end{tabular}

Means followed by the same lowercase letter in the row and upper case in the column do not differ by Scott-Knott's test at the 5\% probability level. Data has been transformed into $\sqrt{\mathrm{x}}$. *Negative Control; FT1- Active ingredients and sprays starting at B1 every 15 days until 75 days as follow: Pyraclostrobin +Fluxapyroxad (B1), Trifloxystrobin + Protioconazol (B1+15), Pyraclostrobin + Fluxapyroxad $(B 1+30)$, Pyraclostrobin+Fluxapyroxad $\quad(B 1+45)$, Pyraclostrobin+Fluxapyroxad $(B 1+60)$, Trifloxystrobin + Protioconazol (B1+75); FT2Active ingredients and sprays starting at B1 every 15 days until 75 days as follow: Azoxystrobin+ Difenoconazole (B1), Difenoconazole (B1+15), Azoxystrobin+ Difenoconazole (B1+30), Azoxystrobin+ Difenoconazole (B1+45), Azoxystrobin+ Difenoconazole (B1+60), Difenoconazole (B1+75).

The highest values of SVWH and SVUP in shorter plants were obtained when no fungicides were used in all cultivars; in particular, FM 975 exhibited high SVWH values (Table 4).

The use of FT1 and FT2 treatments promoted a reduction in SVWH values for the cultivars used, with greater reduction of SVWH values primarily in the cultivars FM 944 and FMT 701. It is likely that the reduction in the efficiency of FT1 and FT2 in cultivar FM 975 relative to that of other cultivars was caused by a greater infection by the pathogen in the lower part of 
the plant. This promotes an increase in the inoculum, and consequently, the progression of the disease.

The behavior of cultivars and fungicide treatments in plants grown at $1.5 \mathrm{~m}$ height in the whole plant and the upper part showed that the cultivars FM 975 and FM 994 for which there was no spray of fungicide (negative control) had higher SVWH and SVUP values. The FT1 and FT2 treatments were efficient in reducing disease severity in the FMT 701 and FM 944 cultivars. However, in the FM 975 cultivar, FT2 was less efficient than was the FT1 treatment (Table 4).

Table 4. Area under ramularia spot progress curve in whole plants (SVWH) and upper portion (SVUP) in two plants height, three cultivars and three fungicides treatments. Chapadão do Sul, MS, Brazil. Crop season 2014/5

\begin{tabular}{|c|c|c|c|c|c|}
\hline \multirow{3}{*}{$\begin{array}{l}\text { Cultivar } \\
\text { treatment } *\end{array}$} & \multirow{3}{*}{ Fungicide } & \multicolumn{2}{|c|}{ SVWH } & \multicolumn{2}{|c|}{ SVUP } \\
\hline & & \multicolumn{4}{|c|}{ Plant height (m) } \\
\hline & & $1 \mathrm{~m}$ & $1,5 \mathrm{~m}$ & $1 \mathrm{~m}$ & $1,5 \mathrm{~m}$ \\
\hline \multicolumn{2}{|c|}{ FMT $701 \mathrm{X}$ Negative control } & $265,51^{\mathrm{bA}}$ & $124,8^{\mathrm{bB}}$ & $65,93^{\mathrm{bA}}$ & $39,58^{\mathrm{bB}}$ \\
\hline \multicolumn{2}{|c|}{ FMT 701 X FT1 } & $55,50^{\mathrm{dA}}$ & $31,71^{\mathrm{cA}}$ & $28,06^{\mathrm{cA}}$ & $16,60^{\mathrm{cA}}$ \\
\hline \multicolumn{2}{|c|}{ FMT 701 X FT2 } & $57,37^{\mathrm{dA}}$ & $39,15^{\mathrm{cA}}$ & $28,84^{\mathrm{cA}}$ & $23,31^{\mathrm{cA}}$ \\
\hline \multicolumn{2}{|c|}{ FM 975 X Negative control } & $537,11^{\text {aA }}$ & $269,37^{\mathrm{aB}}$ & $227,66^{\text {aA }}$ & $80,65^{\mathrm{aB}}$ \\
\hline \multicolumn{2}{|c|}{ FM 975 X FT1 } & $102,05^{\mathrm{cA}}$ & $62,46^{\mathrm{cA}}$ & $61,68^{\mathrm{bA}}$ & $35,66^{\mathrm{bB}}$ \\
\hline \multicolumn{2}{|c|}{ FM 975 X FT2 } & $143,25^{\mathrm{cA}}$ & $83,62^{\mathrm{bB}}$ & $70,41^{\text {bA }}$ & $39,69^{\mathrm{bB}}$ \\
\hline \multicolumn{2}{|c|}{ FM 944 X Negative control } & $296,03^{b A}$ & $282,03^{\text {aA }}$ & $68,93^{\mathrm{bA}}$ & $58,91^{\text {aA }}$ \\
\hline \multicolumn{2}{|c|}{ FM 944 X FT1 } & $81,42^{\mathrm{dA}}$ & $45,94^{\mathrm{cA}}$ & $28,62^{\mathrm{cA}}$ & $23,76^{\mathrm{cA}}$ \\
\hline \multicolumn{2}{|c|}{ FM 944 X FT2 } & $75,72^{\mathrm{dA}}$ & $44,48^{\mathrm{cA}}$ & $28,26^{\mathrm{cA}}$ & $19,83^{\mathrm{cA}}$ \\
\hline \multicolumn{2}{|c|}{$\mathrm{VC}(\%)$} & \multicolumn{2}{|c|}{14,78} & \multicolumn{2}{|c|}{13,55} \\
\hline
\end{tabular}

Means followed by the same lowercase letter in the row and upper case in the column do not differ by Scott-Knott's test at the $5 \%$ probability level. *Negative Control; FT1- Active ingredients and sprays starting at B1 every 15 days until 75 days as follow: Pyraclostrobin +Fluxapyroxad (B1), Trifloxystrobin + Protioconazol (B1+15), Pyraclostrobin + Fluxapyroxad (B1+30), Pyraclostrobin+Fluxapyroxad (B1+45), Pyraclostrobin+Fluxapyroxad $(B 1+60)$, Trifloxystrobin + Protioconazol (B1+75); FT2Active ingredients and sprays starting at B1 every 15 days until 75 days as follow: Azoxystrobin+ Difenoconazole (B1), Difenoconazole (B1+15), Azoxystrobin+ Difenoconazole (B1+30), Azoxystrobin+ Difenoconazole (B1+45), Azoxystrobin+ Difenoconazole (B1+60), Difenoconazole (B1+75).

The plant height factor directly influenced the progression of the disease in the whole plant and in the upper part. In the upper portion, cultivar FMT 701 exhibited the greatest progression of the disease in the absence of fungicide (control) in shorter plants. Cultivar FM 975 presented a higher SVUP value in $1 \mathrm{~m}$ plants for all fungicide treatments. In the whole plant, cultivar FMT 701 showed greater disease progression in shorter plants in the absence of fungicides. For cultivar FM 975, the highest SVWH values were obtained in the control and in shorter FT2 plants. It is hypothesized that because of the shortening of the internodes, the distance between the youngest and oldest leaves of the plants was reduced, favoring the 
dispersion of the pathogenic conidia produced in the lower part of the plants. In addition, it may be that plants with lower height provided greater light penetration within the canopy because they had fewer leaves than larger plants (Sobrinho et al., 2007). As a result, there could have been a higher average daily temperature in the older leaves, and consequently, a more favorable environment for the occurrence of leaf spot (Rathaiah, 1977).

In analyzing the performance of cultivar FM 944 in conjunction with fungicidal treatments (Negative control, FT1, and FT2) at both plant heights in the upper portion and whole plant, similar behavior was noted. SVWH and SVUP values for this cultivar were not influenced by plant height. Yield in the upper portion and in the whole plant exhibited an interaction between plant height and fungicidal treatment. In the lower portion, there were interaction effects between the height of plants and cultivars, and fungicide treatments and cultivars on the yield of cotton boll (Table 5).

Table 5. F values for cotton boll yield in the upper portion (YUP), lower portion (YLOW) and whole cotton plants (YWH). Chapadão do Sul, MS. Crop season 2014/5

\begin{tabular}{lccc}
\hline \multirow{2}{*}{ Variation factors } & \multicolumn{3}{c}{ F value } \\
\cline { 2 - 3 } & YUP & YLOW & YWH \\
\hline Plant height (H) & $9,8297^{*}$ & $0,7422^{\mathrm{ns}}$ & $3,7615^{\mathrm{ns}}$ \\
Cultivar (C) & $8,0612^{*}$ & $8,9931^{*}$ & $10,5746^{*}$ \\
Fungicide treatment (FT) & $2,4732^{\mathrm{ns}}$ & $0,6381^{\mathrm{ns}}$ & $0,6318^{\mathrm{ns}}$ \\
H x C & $1,1215^{\mathrm{ns}}$ & $4,2390^{*}$ & $1,3931^{\mathrm{ns}}$ \\
H x FT & $4,2373^{*}$ & $0,2194^{\mathrm{ns}}$ & $3,5976^{*}$ \\
FT x C & $2,0666^{\mathrm{ns}}$ & $5,4522^{*}$ & $1,2636^{\mathrm{ns}}$ \\
H x C x FT & $0,5229^{\mathrm{ns}}$ & $0,7867^{\mathrm{ns}}$ & $0,9222^{\mathrm{ns}}$ \\
\hline VC (\%) & $11,67^{*}$ & $11,57^{*}$ & $8,28^{2}$ \\
\hline
\end{tabular}

* significant to $5 \%$ probability; ns: not significant.

The negative control showed no difference in yield in the upper part of the plants based on plant height. However, the use of FT1 and FT2 fungicide treatments increased yield by $15.54 \%$ and $14.62 \%$ in the upper portion of shorter plants compared to that of larger ones, respectively (Table 6). Rosolem (2001) found that a greater intensity in the occurrence of pests and diseases in the lower part of the plant impairs the yield of cotton, such that the plant seeks to compensate for the loss by increasing the number of bolls in the upper part of the plant. It is believed that because the shorter plants exhibit higher severity of leaf spot (especially in the lower part), the production of a larger amount of bolls was induced in the upper part.

The use of fungicide treatments did not increase the yield of the upper part of the plant relative to that of the treatment with no spray of fungicide to larger plants $(1.5 \mathrm{~m})$. It is 
hypothesized that the leaf spot did not affect plant yield in the upper portion because the SVUP values were low. In shorter plants, FT1 and FT2 treatments yielded yield gains when compared to that of the treatment with no spray of fungicide to either the upper or whole plant (Table 6). Ascari et al. (2016) reported that chemical control is an important management practice in cotton production because the lower severity of leaf spot may reflect a higher yield.

Table 6. Cotton boll yield (kg.ha $\left.{ }^{-1}\right)$ in upper portion (YUP) and whole cotton plants (YWH) submitted to two cotton plants heigh and three fungicides treatments. Chapadão do Sul, MS. Crop season 2014/5

\begin{tabular}{|c|c|c|c|}
\hline \multirow{2}{*}{$\begin{array}{l}\text { Plant } \\
\text { height (m) }\end{array}$} & \multicolumn{3}{|c|}{ YUP } \\
\hline & Negative control & FT1 & FT2 \\
\hline 1,0 & $2767,2^{\mathrm{aB}}$ & $3238,0^{\text {aA }}$ & 3077,2 aA \\
\hline 1,5 & 2844,7 aA & 2802,4 bA & 2684,6 bA \\
\hline \multirow[t]{3}{*}{$\mathrm{VC}(\%)$} & \multicolumn{3}{|c|}{---------------------11,68--------------------- } \\
\hline & \multicolumn{3}{|c|}{ YWH } \\
\hline & Negative control & FT1 & FT2 \\
\hline 1,0 & $5047,7 \quad$ aB & $5483,8^{\text {aA }}$ & 5332,2 aA \\
\hline 1,5 & $5232,6^{\text {aA }}$ & 5055,1 bA & 4986,6 aA \\
\hline $\mathrm{VC}(\%)$ & $---\cdot-$ & $-8,51-$ & --- \\
\hline
\end{tabular}

Means followed by the same lowercase letter in the row and upper case in the column do not differ by Scott-Knott's test at the $5 \%$ probability level. *Negative Control; FT1- Active ingredients and sprays starting at B1 every 15 days until 75 days as follow: Pyraclostrobin +Fluxapyroxad (B1), Trifloxystrobin + Protioconazol $(\mathrm{B} 1+15)$, Pyraclostrobin + Fluxapyroxad (B1+30), Pyraclostrobin+Fluxapyroxad $\quad(B 1+45)$, Pyraclostrobin+Fluxapyroxad (B1+60), Trifloxystrobin + Protioconazol (B1+75); FT2Active ingredients and sprays starting at B1 every 15 days until 75 days as follow: Azoxystrobin+ Difenoconazole (B1), Difenoconazole (B1+15), Azoxystrobin+ Difenoconazole $(\mathrm{B} 1+30)$, Azoxystrobin+ Difenoconazole $(\mathrm{B} 1+45)$, Azoxystrobin+ Difenoconazole (B1+60), Difenoconazole $(\mathrm{B} 1+75)$.

The total yield of the plants receiving the FT1 fungicide treatment increased by $8.48 \%$ in the shorter plants in relation to that of the taller ones (Table 6). The use of a growth regulator to reduce plant size provides a greater balance between reproductive and vegetative parts, which favors reduced competition for photoassimilates between vegetative and reproductive growth (Lamas and Ferreira, 2015). Furthermore, it promotes higher fruit retention in the first positions, a fact that culminates in higher yield (Echer and Rosolem, 2012). The cultivar FM 975 produced the largest amount of cotton boll relative to that of the other cultivars (Table 7), although it was the genotype that presented the highest severity of leaf spot (Table 4). 


\section{$\triangle$ Macrothink}

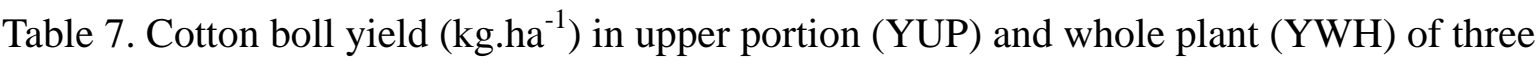
cotton cultivars. Chapadão do Sul, MS, Brazil. Crop season 2014/5

\begin{tabular}{lcc}
\hline \multirow{2}{*}{ Cultivar } & \multicolumn{2}{c}{ Cotton boll yield $\left({\left.\mathrm{kg} . h a^{-1}\right)}\right.$} \\
\cline { 2 - 3 } & YUP & YWH \\
\hline FMT 701 & $2884,9^{\mathrm{b}}$ & $4988,4^{\mathrm{b}}$ \\
FM 975 & $3106,7^{\mathrm{a}}$ & $5516,2^{\mathrm{a}}$ \\
FM 944 & $2715,9^{\mathrm{b}}$ & $5064,3^{\mathrm{b}}$ \\
\hline VC $(\%)$ & 11,68 & 8,51 \\
\hline
\end{tabular}

Means followed by the same letter do not differ by Scott-Knott's test at the 5\% probability level

There was an interaction between cultivars and fungicide treatments for yield in the lower plant portion (Table 8). The cultivar FMT 701 was not influenced by fungicidal treatments. and the cultivar FM 944 showed higher yield with the use of the FT2 fungicide treatment. Silva et al. (2017) verified that the severity of ramularia spot was reduced using varieties tolerant or resistant in combination with another control method, such as biological control or a chemical fungicide. They concluded that an integrated management, with an emphasis on the strategies of adopting resistant cotton varieties and spraying fungicides and biocontrol agents such as Trichoderma asperellum, was desirable for efficient control of ramularia spot on cotton.

Table 8. Cotton boll yield $\left(\mathrm{kg} \cdot \mathrm{ha}^{-1}\right)$ in lower portion (YLOW) of three cultivars submitted to three fungicides treatments and two plants height. Chapadão do Sul, MS. Crop season 2014/5

\begin{tabular}{|c|c|c|c|}
\hline \multirow{3}{*}{$\begin{array}{l}\text { Fungicide } \\
\text { treatment* }\end{array}$} & \multicolumn{3}{|c|}{ YLOW } \\
\hline & \multicolumn{3}{|c|}{ Cultivar } \\
\hline & FMT 701 & FM 975 & FM 944 \\
\hline Negative control & $2097,0^{\mathrm{aB}}$ & $2709,0^{\text {aA }}$ & $2196,4^{\mathrm{bB}}$ \\
\hline FT1 & $2175,2^{\text {aA }}$ & $2225,9^{\mathrm{bA}}$ & $2317,2^{\mathrm{bA}}$ \\
\hline FT2 & $2038,0^{\mathrm{aB}}$ & $2264,2^{\mathrm{bB}}$ & $2532,9^{\text {aA }}$ \\
\hline \multicolumn{4}{|l|}{ Plant height (m) } \\
\hline 1,0 & $2185,0^{\mathrm{aA}}$ & $2268,7^{\mathrm{bA}}$ & $2327,4^{\mathrm{aA}}$ \\
\hline 1,5 & $2021,9^{\mathrm{aB}}$ & $2550,2^{\text {aA }}$ & $2370,4^{\mathrm{aA}}$ \\
\hline $\mathrm{VC} \%$ & ------------- & $-11,57---$ & ----------- \\
\hline
\end{tabular}

Means followed by the same lowercase letter in the row and upper case in the column do not differ by Scott-Knott's test at the 5\% probability level. *Negative Control; FT1- Active ingredients and sprays starting at B1 every 15 days until 75 days as follow: Pyraclostrobin +Fluxapyroxad (B1), Trifloxystrobin + Protioconazol (B1+15), Pyraclostrobin + Fluxapyroxad (B1+30), Pyraclostrobin+Fluxapyroxad $\quad(B 1+45)$, Pyraclostrobin+Fluxapyroxad $(\mathrm{B} 1+60)$, Trifloxystrobin + Protioconazol (B1+75); FT2Active ingredients and sprays starting at B1 every 15 days until 75 days as follow: Azoxystrobin+ Difenoconazole (B1), Difenoconazole (B1+15), Azoxystrobin+ Difenoconazole (B1+30), Azoxystrobin+ Difenoconazole (B1+45), Azoxystrobin+ Difenoconazole (B1+60), Difenoconazole (B1+75). 
In general, the cultivars presented different results regarding yield in the lower portion. Thus, yield improvement with fungicidal treatment appeared to be dependent upon the cultivar under study. Dias and Theodoro (2017) obtained similar results and showed that yield in the lower portion was directly influenced by the fungicide program and cultivar. Plant height influenced yield only in cultivar FM 975, for which larger plants had higher yields than shorter ones. This result may be caused by the lower severity in taller plants, a fact that allowed cultivar FM 975 to produce a higher yield (Table 8). The interactions between cultivar, plant height, and fungicidal treatment could generate specific and more efficient strategies for the control of leaf spot and may guarantee higher yields. In addition, this study produced important information to better elucidate the disease process in plants grown at different times, showing the importance of the correct use of growth regulators.

\section{Conclusions}

Cultivar FM 975, when cultivated at $1 \mathrm{~m}$ height and without fungicide spray, showed a greater progression of leaf spot disease. The use of fungicides was efficient in reducing the severity of leaf spot. The use of fungicides in shorter plants $(1 \mathrm{~m})$ increased yield. Cultivar FM 975 obtained the highest total yield.

\section{Acknowledgements or Sponsoring information}

This study was financed in part by the Coordenação de Aperfeiçoamento de Pessoal de Nível Superior - Brasil (CAPES) - Finance Code 001. The authors thank to Universidade Federal de Mato Grosso do Sul.

\section{References}

Agrios, G. N. (2005). Plant pathology. 5.ed., Academic Press. 952p.

Aquino, L. A., Berger, P. G., Rodrigues, F. A., Zambolim, L., Hernandez, J. F. R., \& Miranda, L. M. (2008). Elaboração e validação de escala diagramática para quantificação da mancha de ramulária do algodoeiro. Summa Phytopathologica, 34, 361-363.

https://doi.org/10.1590/S0100-54052008000400012

Ascari, J. P., Araújo, D. V., Dias, L. D. E., Bagatini, G. J., \& Mendes, I. R. N. (2016). Severity of ramularia leaf spot and seed cotton yield in different sowing times. Revista Caatinga, 29, 603-610. https://doi.org/10.1590/1983-21252016v29n310rc

Campbell, C. L., \& Madden, L. V. (1990). Introduction to plant disease epidemiology. 1.ed New York: John Wiley. 532 p.

Cia, E., Fuzatto, M. G., Kondo, J. I., Ohl, G. A., \& Galbieri, R. (2013). Reação de genótipos de algodoeiro à mancha de Ramularia em diferentes épocas e ambientes. Summa Phytopathologica, 39, 193-197. https://doi.org/10.1590/S0100-54052013000300008

Cordão Sobrinho, F. P., Fernandes, P. D., Beltrão, N. E. M., Soares, F. A. L., \& Terceiro Neto, C. P. C. (2007). Crescimento e rendimento do algodoeiro BRS-200 com aplicações de cloreto de mepiquat e lâminas de irrigação. Revista Brasileira de Engenharia Agrícola e Ambiental, 11, 284-292. https://doi.org/10.1590/S1415-43662007000300007

Dias, A. R., \& Theodoro, G. F. (2017). Integração de cultivares resistentes e fungicidas no 
controle da mancha de ramulária (Ramularia areola) e produtividade do algodoeiro. Revista de Ciências Agroveterinárias, 16, 221-230. https://doi.org/10.5965/223811711632017221

Echer, F. R., \& Rosolem, C. A. (2012). Plant growth regulator losses in cotton as affected by adjuvants and rain. Ciência Rural, 42, 2138-2144.

https://doi.org/10.1590/S0103-84782012005000120

Garcia, S., Cordeiro, A., Alencar, N. A. A. S. I., \& Costa Neto, P. L. O. (2019). The sustainability awareness of Brazilian consumers of cotton clothing. Journal of Cleaner Production, 215, 1490-1502. https://doi.org/10.1016/j.jclepro.2019.01.069

Girotto, L., Marangoni, M. S., Matos, J. N., Galbieri, R., Almeida, W. P., \& Mehta, Y. R. (2013). Identification of phenotypic and genotypic variability among the isolates of Ramularia areola of brazilian cotton. American Journal of Plant Sciences, 4, 1893-1898. https://doi.org/10.4236/ajps.2013.49232

Guazina, R. A., Nass, R. A. R., Theodoro, G. F., Brumatti, R. C., Muchalak, S. M., \& Golin, H. O. (2019). Agronomic and economic evaluation of sequential spray of silicon and fungicides for a sustainable soybean crop. Journal of Agricultural Studies, 8, 1-16.

https://doi.org/10.5296/jas.v8i2.15676

Johnson, I., Ramjegathesh, R., Karthikeyan, M., \& Chidambaram, P. (2013). Epidemiology of grey mildew and Alternaria blight of cotton. Archives of Phytopathology and Plant Protection, 46, 2216-2223. https://doi.org/10.1080/03235408.2013.789183

Lamas, F. M., \& Ferreira, A. C. B. (2015). Manejo das principais doenças do algodoeiro no cerrado brasileiro. In: FREIRE, E.C. Algodão no cerrado do Brasil. 3 ed. Brasília: Abrapa, p. 559-582.

Lima, L. L., Barreto, M., \& Scaloppi, E. A. G. (2010). Reação de cultivares de algodoeiro a Ramularia areola. Summa Phytopathologica, 36, 57-60.

https://doi.org/10.1590/S0100-54052010000100010

Lopes, L. O., Lacerda, J. J. J., Mielezrski, F., Ratke, R. F. E, Lira, D. N. S., \& Pacheco, L. P. (2017). Efeito de fungicidas para o controle da Ramularia areola na cultura do algodoeiro. Summa Phytopathologica, 43, 229-235. https://doi.org/10.1590/0100-5405/2203

MAPA. AGROFIT. http://agrofit.agricultura.gov.br/agrofit_cons/principal_agrofit_cons, Access: 11.11.2019.

Marois, J. J., Wright, D. L., Wiatrak, P. J., \& Vargas, M. A. (2004). Effect of row width and nitrogen on cotton morphology and canopy microclimate. Crop Science, 44, 870-877. https://doi.org/10.2135/cropsci2004.8700

Marur, C. J., \& Ruano, O. A. (2001). Reference system for determination of developmental stages of upland cotton. Revista Brasileira de Oleaginosas e Fibrosas, 5, 313-317.

Monteith, J. L., \& Unsworth, M. H. (1990). Principles of environmental physics. 2 ed. New York: Edward Arnold. 291p.

Pimentel, D. (2005). Environmental and economic costs of the spray of pesticides primarily in the United States. Environment, Development and Sustainability, 7, 229-252. https://doi.org/10.1007/s10668-005-7314-2 
Prakash, A. H., Sankaranayaranan, K., \& Sabesh, M. (2019). AICRP on cotton - fifty years of tireless research on nutritional management for sustainable cotton production. Indian Journal of Fertilizers, 15, 450-464.

Punit, M., Mukewar, P. M., Raj, S., \& Singh, V. V. (1997) Anatomy of Gossypium arboreum lines immune to grey mildew disease. Journal of Cotton Research and Development, 11, 191-195.

Rathaiah, Y. (1977). Spore germination and mode of action of cotton infection by Ramularia areola. Phytopathology, 67, 351-357. https://doi.org/10.1094/Phyto-67-351

Rosolem, C. A. (2001). Ecofisiologia e manejo da cultura do algodoeiro. Informações Agronômicas, 95, 1-2.

Shete, P. P., Kasal, Y. G., \& Perane, R. R. (2018). Screening of the cotton genotypes against Ramularia areola ATK. under field condition. Plant Archives, 18, 734-736.

Silva, J. C., Suassuna, N. D., \& Bettiol, W. (2017). Management of Ramularia leaf spot on cotton using integrated control with genotypes, a fungicide and Trichoderma asperellum. Crop Protection, 4, 28-32. https://doi.org/10.1016/j.cropro.2016.12.006

Silva, R. R., Theodoro, G. F., \& Staudt, R. C. (2010). Avaliação da incidência de doenças em algodoeiros cultivados na região de Chapadão do Sul. Revista Brasileira de Oleaginosas e Fibrosas, 14, 91-95.

Sobrinho, F. P. C., Fernandes, P. D., Beltrão, N. E. M., Soares, F. A. L., \& Terceiro Neto, C. P. C. (2007). Crescimento e rendimento do algodoeiro BRS-200 com aplicações de cloreto de mepiquat e lâminas de irrigação. Revista Brasileira de Engenharia Agrícola e Ambiental, 11, 284-292. https://doi.org/10.1590/S1415-43662007000300007

Sousa, D. M., \& Lobato, E. (2004). Cerrado: correção do solo e adubação. 2 ed. Brasília: Embrapa, 416p.

Suassuna, N. D., \& Coutinho, W. M. (2015). Manejo das principais doenças do algodoeiro no cerrado brasileiro. In: FREIRE, E.C. Algodão no cerrado do Brasil. 3 ed. Brasília: ABRAPA. p. 305-408.

Volponi, J., Matos, J. N., Girotto, L., Marangoni, M. S., Galbieri, R., \& Mehta, Y. R. (2014). Spore types and spore production of Ramularia areola for screening cotton germplasm for resistance. American Journal of Plant Sciences, 5, 2413-2417.

https://doi.org/10.4236/ajps.2014.515254

Zulfiqar, F., \& Thapa, G. B. (2018). Determinants and intensity of adoption of "better cotton" as an innovative cleaner production alternative. Journal of Cleaner Production, 172,

3468-3478. https://doi.org/10.1016/j.jclepro.2017.09.024

\section{Copyright Disclaimer}

Copyright for this article is retained by the author(s), with first publication rights granted to the journal.

This is an open-access article distributed under the terms and conditions of the Creative Commons Attribution license (http://creativecommons.org/licenses/by/4.0/). 